\title{
Determination of Parasite Fauna on Freshwater Crayfish "Asta- cus leptodactylus" (Eschscholtz, 1823) In the Arass Dam Reservoir, Northwest of Iran
}

\section{Mehrdad Asgharnia*}

Iranian Fisheries Science Research Institute, Inland Waters Aquaculture Research Center, Agricultural Research Education and Extension Organization (AREEO), Bandar-e-Anzali -Iran

"Corresponding author: Mehrdad Asgharnia, Aquatic health \& diseases department expert, Iranian Fisheries Science Research Institute, Inland waters aquaculture Research Center, Agricultural Research Education and Extension Organization (AREEO), Bandar-e-Anzali-Iran. Tel: +984442052; Fax: +9844423070; Email: Mehrdad_asgharnia@yahoo.com

Citation: Asgharnia M (2017) Determination of Parasite Fauna on Freshwater Crayfish "Astacus leptodactylus" (Eschscholtz, 1823) In the Arass Dam Reservoir, Northwest of Iran. J Fish Aqua Dev: JFAD-128. DOI:10.29011/JFAD-128/100028

Received Date: 9 October, 2017; Accepted Date: 21 October, 2017; Published Date: 30 October, 2017

\begin{abstract}
During the research, from date May 24 to June 26 in year 2015, about 140 specimens of freshwater crayfish with scientific name "Astacus leptodactylus" were captured by funnel baited traps from different stations of the lake and transported to laboratory. A total range of 68 freshwater crayfish specimens out of 140 crayfish with Prevalence rate equal to \% 48.5 and mean infection intensity of 4.6, were affected by a kind of parasite called, Branchiobdella hexodonta. This parasite was recovered from carapace and gills of the crustacea. The highest number range of parasite (1-23 number) was seen in length range of 10.6-12.6 cm and the lowest number range of parasite (1-11number) observed in length range between 12.7 to $14.9 \mathrm{~cm}$. Maximum mean intensity (6.3 number) was in length range of $10.6-12.6 \mathrm{~cm}$ and minimum mean intensity (3.1 number) was between 12.7 to 14.9. Maximum average abundance (3.6 number) was in length range 10.6-12.6, while minimum average abundance (0.88 number), accounted in length range $8.1-10.5 \mathrm{~cm}$. prevalence rate (32\%) and mean intensity $(4.3)$ in carapace was higher, in comparison to gills, with prevalence and mean intensity of $20.9 \%$ and 2.8 , respectively. by increasing length size of crayfish, prevalence rate was increased too. It is worthy of mention that, this worm only parasitism freshwater crayfish, and crayfish is specific host for the parasite. Meanwhile, Annelida Branchiobdella hexodonta, which known as crayfish "Branch worm" is reported for the first time from Iran freshwater crayfish. this worm only parasitism freshwater crayfish and is host specific for crayfish. finally, nematode larvae of Rhabdochona sp. and Cystidicola sp. have not parasitic nature and only have a Commensal state or free-living form, and crayfish act as an intermediate host for them.
\end{abstract}

Keywords: Branchiobdella; Crustacea, Epibiont; Environment infection; Natural

\section{Introduction}

Arass dam reservoir is a border lake between countries Iran and self-governed of Nakhchivan Republic with special features that its variety of fish species and natural food led to fishing activities in the lake without considering principles of maintaining reserves such as fishing time and fishing location, annual extraction can cause damage to both sides sources. This reservoir dam is located on border river between Iran and Nakhchivan, $40 \mathrm{~km}$ west of Jolfa, called Ghezel Ghashlagh $\left(45^{\circ} 2^{\prime} \mathrm{N}, 39^{\circ} 8^{\prime} \mathrm{W}\right)$, which was constructed in year 1971. Freshwater crayfish with scientific name
"Astacus leptodactylus" (Family; Astacidae) is one of important crustacean species in this lake. freshwater crayfish is a valuable benthic organism that has entered the lake, its population increased accidentally and during the past 15 years its commercial harvest has begun. It is a precious water refiner and great deal of economic and nutritional value which attention has attracted toward it. freshwater crayfish in terms of classification stands at the widest category level of crustacean. They belong to the subclass of Malacostraca and order of Decapoda. They have been raised to act as human food consumption for many years. Cannibalism and susceptibility to diseases are natural features of this beast and large predatory creatures tend to hunt it. Crayfish host a wide range of parasites. Among the factors causing crayfish parasitic diseases, 


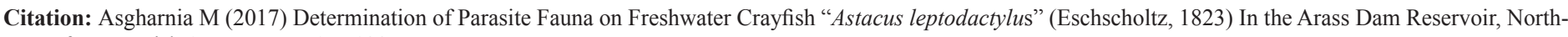
west of Iran. J Fish Aqua Dev: JFAD-128.

Annelida or ringworm served as a major role in crayfish infections and enjoys of specific position and importance. in terms of classification, Bronchiobdellida are member of phylum; Annelida and order; Hirudinea, that habitat on carapace and gills of crayfish. aquaculture not only allows for better monitoring of populations health status, but also provides an environment for more efficient transmission of many pathogens and expression of associated diseases, whether or not a crayfish will succumb to a disease, or become heavily infested with an epibiont organism, is dependent on factors relating to the host, environment and the invading organism. This classical relationship of pathogen-host-environment becomes more critical as aquaculture intensification increases. Pathogens vary in their pathogenicity, the ability that cause disease. The presence of pathogens in crayfish tissues does not necessarily result in an observable detrimental effect on the crayfish. crayfish can act as pratenic or intermediate hosts to a number of metazoan parasites, the parasite encysting in the tissues of the crayfish and remaining in an inactive state until the crayfish dies or is eaten by a predator. In such cases the parasite does not have a deleterious effect on crayfish, unless it blocks vital functioning of an organ. Host factors influencing disease outbreaks primarily relate to the resistance of the animal to invasion of its tissues by the pathogen. Resistance to infection or infestation is dependent on the existing health status of host at time of exposure, which is in turn determined by prior exposure to environmental stressors and by inherited Immunocompetence characteristics [1-4]. Environmental factors were influenced the occurrence of disease conditions or epibiont infestations, comprise water quality conditions and environmental perturbations such as exposure to air or physical disturbance events. These factors were affected the ability of crayfish to resist the infection or infestation, for example physical handling causes stress responses in freshwater crayfish that if excessive or prolonged, have an adverse effect on immunocompetence and predispose the crayfish to disease [5]; Conversely an excessive epibiont infestation of freshwater crayfish is often caused by poor water quality conditions that lead to the overgrowth by the epibiont regardless of the health status of the host [6]. The leech like Branchiobdellids are symbionts found mainly on freshwater Astacid crayfish in the Holarctic water. They are minute flattened, vermiform animals, members of the only parasitic family of the Oligochaete annelid worms. The head has developed to form a sucker with a circle of finger-like projections and the buccal cavity contains two Chitinous jaws. The posterior segments are also modified to form a sucker, and none has chaetae. Both suckers are used for attachment and movement on the host. All Branchiobdellids are small and consist of a maximum of 14 to 15 segments. The taxonomy of the group has been extensively studied [7-9] and comprehensive descriptions of Branchiobdellid infestations of crayfish from specific locations or taxonomic groups are also provided [10,11]. They are mostly found as epicommensals adhering to the external surfaces of crayfish and have been reported as associates of crayfish throughout N. America, Europe and East Asia including Japan. Numerous genera of Branchiobedellids are described with the largest number of North American species belonging to Cambarinocola and all the European species belonging to the genus Branchiobdella. In European crayfish seven species of branchiobodella have been recorded [12]. In Estonia three species of branchiobdellids have been found on noble crayfish. Branchiobdella pentodonta (see Figure 4) was found mainly in western Estonia and on the islands Saaremaa, Huumaa, and muhumaa, while $B$. astaci was common in the south and east, $B$. parasitica was found to be more widespread [13]. In poland, five species of the genus branchiobodella have been registered on noble and narrow-clawed crayfish. The most frequently recorded species was $B$. parasitica which was found in all sites and on $75 \%$ of the crayfish [12]. Three species of Branchiobdella are registered in Bavaria [14]. The crayfish is essential for the reproductive process of Branchiobdellids. For the adults they merely serve to carry the worms and to offer an area for feeding on the abundant detritus and epibionts adhering to the crustacean surface [15]. They have demonstrated a little species characteristic, although from western and Eastern groups of crayfish in America, special species of Branchiobdella have been recovered [16]. In some cases, up to six different species have been observed on the body of a single host [9]. Additionally, some N. American branchiobdellids have very specific attachment sites on their hosts [11]. This is particularly evident when two or more species of branchiobdellid infest the same crayfish. There are several researches have been conducted around fish parasitic infections in Iranian inland waters, but unfortunately there is no report about freshwater crayfish parasitic diseases or infection, and is the first report of its kind. This survey was aimed to identify and introduce "Branchiobdella hexodonta" recovered from freshwater crayfish Astacus leptodactylus and determined the prevalence rate, mean intensity and frequency of the worm infestation.

\section{Materials \& Methods}

The research was carried out in Astaneh research station at different seasons between years 2014 and 2015. more than 140 individual specimens of freshwater crayfish were trapped by fyke net in random sampling from the Astaneh station cultivated pounds with different length size and transported alive in water obtained from the collection site, to the parasitology laboratory of aquatic health and disease department, then biometric characteristics like weight measurement and sex determination were recorded each by each crayfish. Crayfish body length was measured as Total Length (TL) with a slide caliper and weight using a digital Balance. The crayfish body was grossly examined for presence of parasites. Samples were collected from external surfaces of animal such as carapace, eyes and bronchial chambers which is covered by carapace, also visceral organs like heart, muscles, hepatopancreas and intestine. All specimens exactly observed through dissection microscope to search probable parasites. Small worms "Branchiob- 


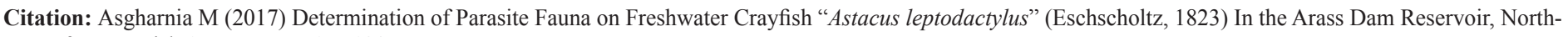
west of Iran. J Fish Aqua Dev: JFAD-128.

dellides" were removed from carapace of their hosts. Specimens obtained from carapace and gills were then placed in containers fill with formalin and being preserved in laboratory in various concentrations of ethanol or 10\% buffered solution of formaldehyde containers. any Branchiobdellidans were then removed and placed in vials with $70 \%$ ethanol for storage. The number of Branchiobbdellidans found per crayfish varied (from 1 to more than 100). Next, all specimens selected for identification were dehydrated in a graded ethanol solution series, cleared in methylsalycylate, infiltrated with Canada balsam, mounted on slides under a cover glass according to method suggested by Gelder et al. (1994,1999) [8,17] and identified using carmine stain and Gelder et al. (1994) [8] Keys. At the end, numeric data were analysis and occurrence and mean intensity were accounted.

\section{Results}

During this study a total number of 140 individual's freshwater crayfish with length range between $8.1 \mathrm{~cm}-14.9 \mathrm{~cm}$ were collected and examined. Approximately 68 specimens of them with prevalence value equal to $48.5 \%$ and mean intensity value of 2.9 were at least infected to one of three kinds of parasite species Including; Branchiobdella hexodonta that is member of phylum Annelida, along with Rhabdochona sp. and Cystidicola sp. those are belong to phylum nematodes. Number of infected crayfish relative to these parasites was vary from 3 to 21 specimens (Table 1 ).

\begin{tabular}{|c|c|c|c|c|c|c|c|}
\hline Dominance & $\begin{array}{c}\text { Mean } \\
\text { abundance }\end{array}$ & $\begin{array}{c}\text { Mean } \\
\text { intensity }\end{array}$ & $\begin{array}{l}\text { Prevalence } \\
\text { rate }\end{array}$ & Frequency & $\begin{array}{c}\text { Parasite } \\
\text { Number Range }\end{array}$ & $\begin{array}{l}\text { Infected } \\
\text { number }\end{array}$ & $\begin{array}{l}\text { Parasite } \\
\text { Speices }\end{array}$ \\
\hline 70 & 1 & 3.3 & 30 & 70 & $1-7$ & 21 & $\begin{array}{c}\text { Branchiobdella } \\
\text { hexodonta }\end{array}$ \\
\hline 22 & 0.1 & 1.6 & 18.5 & 22 & $1-4$ & 13 & Rhabdochona sp. \\
\hline 7 & 0.1 & 3.3 & 4.2 & 7 & $1-5$ & 3 & Cystidicola sp. \\
\hline 99 & 1.4 & 2.9 & 48.5 & 99 & $1-7$ & 68 & Total \\
\hline
\end{tabular}

Table 1: Parasite Frequency Infection Rate of Freshwater Crayfish in Aras Dam Reservoir.

Maximum number of crayfish infected to Branchiobdella hexodonta were 21 specimens and minimum number of crayfish infected to Cystidicola sp. were 3 specimens. Mean intensity value was vary from minimum 1.6 to maximum 3.3 number. The lowest parasitic number for each species was 1 and the highest number of parasite that observed in Branchiobdella hexodonta were 7 individuals. Parasite abundance value were between 7 and 70 numbers (Table 1). The lowest abundance value was seen in Cystidicola sp. nematode and the highest abundance value seen in Annelida; Branchiobdella hexodonta. The lowest prevalence value was observed in Cystidicola sp. and the highest prevalence value observed in Branchiobdella hexodonta. Also, the lowest and highest mean intensity value were found in Rhabdochona sp. and Branchiobdella hexodonta respectively (Table 2).

\begin{tabular}{|c|c|c|c|c|c|}
\hline Dominance & Mean abundance & Mean intensity & Infected crayfish & Parasite frequency & Rhabdochona speices \\
\hline 66 & 0.16 & 0.36 & 12 & 8 & R. denudata \\
\hline 25 & 0.06 & 0.13 & 6 & 3 & R. hellichi \\
\hline 25 & 0.06 & 0.13 & 6 & $\mathbf{1 4}$ & Tortunatowi \\
\hline $\mathbf{1 1 6}$ & $\mathbf{0 . 2 8}$ & $\mathbf{0 . 6 2}$ & $\mathbf{2 4}$ & Total \\
\hline
\end{tabular}

Table 2: Frequently Distribution of Parasitic Infection in Freshwater Crayfish Due to Rhabdochona Species in Arass Dam Lake.

Mean abundance value was determined in range between 0.1-1 numbers, which Cystidicola sp. was allocated the least and Branchiobdella hexodonta had the meanest abundance value. The most dominance was belonged to Branchiobdella sp. and the least dominance was allocated to Cystidicola sp. alongside with increasing average length, prevalence value was declined, and mean intensity infection increased and conversely (Table 3).

\begin{tabular}{|c|c|c|c|c|c|}
\hline Prevalence & Mean intensity & Parasite frequently & Infected number & Crayfish & Number N=140 \\
\hline $18.1 \%$ & 5.8 & 35 & 12 & Average length & $12.55 \mathrm{n}=66$ \\
\hline $40.5 \%$ & 2.3 & 35 & 35 & Average length & $10.42 \mathrm{n}=74$ \\
\hline
\end{tabular}

Table 3: Relation between crayfish average length with Branchiobdella sp. infection rate. 


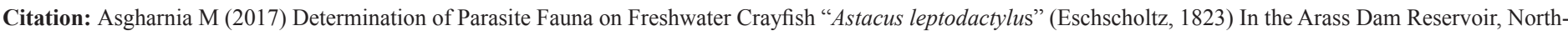
west of Iran. J Fish Aqua Dev: JFAD-128.

Number of female crayfish affected to Cystidicola sp. were 2 individuals (the lowest) and female crayfish that infected to Branchiobdella hexodonta were 15 individuals (the highest). In males, only one individual crayfish was infected to Cystidicola sp. and 9 others were infected to Rhabdochona sp. which were encountered the least and the most rate of infection relatively. The most number of infected crayfish was related to females and the least number reported from males (Table 4).

\begin{tabular}{|c|c|c|c|c|}
\hline Number of parasite in male & $\begin{array}{c}\text { Number of parasite in } \\
\text { female }\end{array}$ & $\begin{array}{c}\text { Number of infected } \\
\text { male }\end{array}$ & $\begin{array}{c}\text { Number of infected } \\
\text { female }\end{array}$ & Parasite/ sex \\
\hline 25 & 45 & 6 & 15 & Brannchiobdella hexodonta \\
\hline 14 & 8 & 9 & 4 & Rhabdochona sp. \\
\hline 1 & 6 & 1 & 2 & Cystidicola sp. \\
\hline $\mathbf{4 0}$ & $\mathbf{5 9}$ & $\mathbf{1 6}$ & $\mathbf{2 1}$ & Total \\
\hline
\end{tabular}

Table 4: Frequently distribution of parasites in freshwater crayfish due to sex in Arass dam lake.

Overall, number of parasites have been isolated from female crayfish were more than male one. In males, frequency limit of parasites was between 1-25 individuals. Maximum frequency of parasites was belonged to Branchiobdella sp. and minimum frequency of parasites allocated to Cystidicola sp. parasitic frequency limit in females were between 6-45 individuals. Again, maximum number of parasites was Belonged to Branchiobdella sp. and minimum number of parasites was observed in Cystidicola sp. According to Table 4, carapace and gills are the only infected organs and others had no evidence of infestation with parasite. Frequency range of collected parasites were limited to 1-43 numbers. The highest parasite number was related to Branchiobodella sp., which recovered from gill tissue (43 number), and Cystidicola sp. had the lowest number (Just one). On carapace; the least parasite number "Cystidicola sp." have been seen (only one). and the most parasite number was occurred in Branchiobdella sp. with 27 numbers (Table 5).

\begin{tabular}{|c|c|c|c|c|c|c|c|}
\hline Eyes & Muscle & Heart & Gut & Hepato-pancrease & Gills & Carapace & Parasite/ Infected Organ \\
\hline- & - & - & - & - & 43 & 27 & Branchiobdella hexodonta \\
\hline- & - & - & - & - & 22 & - & Rhabdochona sp. \\
\hline- & - & - & - & - & 6 & 1 & Cystidicola sp. \\
\hline- & - & - & - & - & $\mathbf{7 1}$ & $\mathbf{2 8}$ & Total \\
\hline
\end{tabular}

Table 5: Distribution Parasitic Infection Rate of Freshwater Crayfish Due to Studied Organs in Arass Dam Lake

As indicated at (Table 6), of 21 crayfish individuals that has infected to Branchiobdella hexodonta, the most number was occurred on females (15 numbers) and the least reported from males (6 numbers).

\begin{tabular}{|c|c|c|c|c|}
\hline Mean intensity & Prevalence & Parasite frequency & Infected number & Crayfish Sex \\
\hline 3 & 62.5 & 45 & Female $\mathrm{n}=24$ & 6 \\
\hline 4.1 & 13 & 25 & 21 & Male $\mathrm{n}=46$ \\
\hline 3.3 & 30 & 70 & Total=70 \\
\hline
\end{tabular}

Table 6: Changes of Branchiobdella hexodonta abundance due to crayfish sex in Arass dam lake

Also, frequency of parasites in female sex (45 numbers) was more than male sex ( 25 numbers). Thus, prevalence value of parasites in females was more than males, but mean intensity in females was less than male one. As shown by (Table 2), of 21 total crayfish individuals that have been infected to Branchiobdella sp., 13 numbers were recovered from gills and 8 numbers were seen on carapace. Parasitic frequency on gills (43 numbers) was more than on carapace (27 numbers). So mean infection intensity on gills was higher than on carapace (Table 7).

\begin{tabular}{|c|c|c|c|c|}
\hline Mean intensity & Prevalence & Parasite frequency & Infected number & Infected organ \\
\hline 2.04 & 18.5 & 43 & 13 & Gills \\
\hline 1.28 & 11.4 & 27 & Carapace & Total \\
\hline $\mathbf{3 . 3 2}$ & $\mathbf{3 0}$ & $\mathbf{7 0}$ & $\mathbf{2 1}$ & \\
\hline
\end{tabular}

Table 7: Infection Rate of External Organs of Freshwater Crayfish Due to Branchiobdella Sp. In Arass Dam Reservoir. 


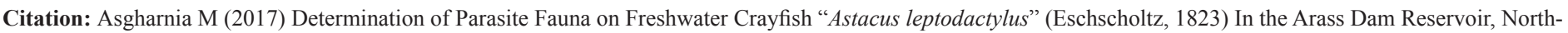
west of Iran. J Fish Aqua Dev: JFAD-128.

\section{Disscussion}

Among freshwater crayfish pararsitic pathogens ringworms have a great impression on infectious diseases and shares a special locality and important characteristic on infecting crayfish. They are exclusively ectoparasites or commensals of crayfish and a few number of other freshwater crustaceans [18]. The former, which is more abuundant, is an ectocommensal species living mainly on the external surface of the freshwater crayfish shell (Exoskeleton); the latter, which is uncommon, is an ectoparasite found primarily on the bronchial chambers of crayfish $[4,8]$.One of the parasite species causes infection on freshwater crayfish is called "Branchiobdella hexodonta" which recovered from carapace and gills (Figure 1\&2).

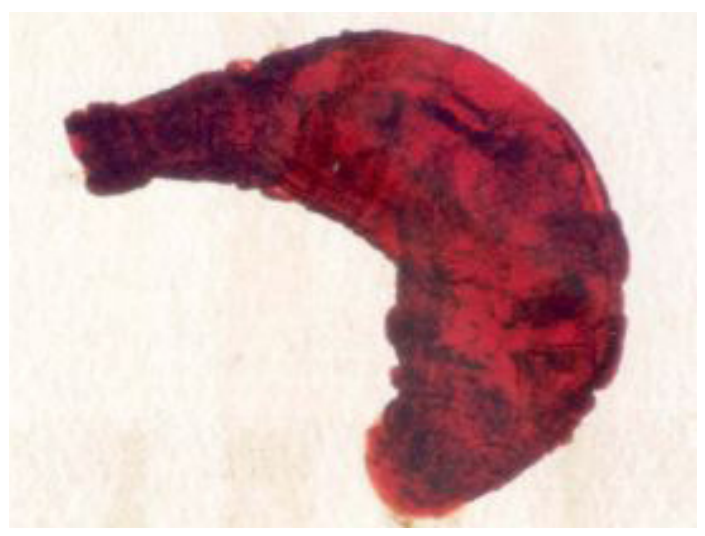

Figure 1: Branchiobdella hexodonta parasite recovered from Carapace of freshwater Crayfish "Astacus leptodactylus" stained with acetocarmine, magnification $200 \mathrm{X}$ (original).

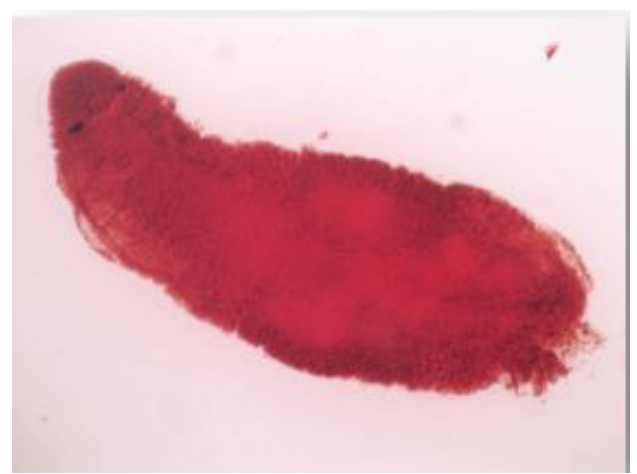

Figure 2: Branchiobdella hexodonta isolated from gill of freshwater crayfish Astacus leptodactylus in Arass damlake, stained with acetocarmine, magnification 200X (original).

The worm first time reported by Mazzarelli (1903) [19] from northern Italy and once again reviewed in year 1906 when he identified Branchiobdella pentodonta (Figure 3) species from crayfish Potamobius pallipes or Austropotamobius pallipes in Milan aquarium.

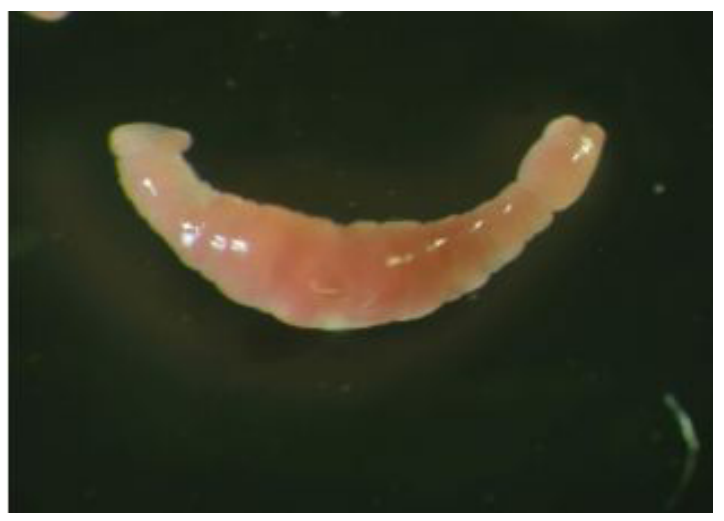

Figure 3: Branchiobdella pentodonta Recovered from Freshwater Crayfish.

Although there have been a number of reports about Branchiobdellids being able to Survive without a crayfish host $[10,20,21]$ they are not thought to be capable of spending any appreciable length of time living independent of the host [9]. The Branchiobdellidans were blamed for damaging the gills and blocking the respiratory water flow to the gills, resulting in a detrimental condition named "Branchiobdellosis" [19]. Although most species are regarded as epicommensals, gill damage is common, particularly in cases of heavy infestations $[18,22]$ and evidence has been obtained for at least one species, called Branchiobdella hexodonta (Figure $1 \& 2$ ), feeding on crayfish tissues [21]. During the research, it was revealed that by increasing total body length range of the freshwater crayfish, prevalence value of parasitic infection increased too $(14.7 \%, 57 \%, 69.2 \%$ respectively) which means, there is a positive relationship between host body size and infestation occurrence of Branchiobodella worms. The reason why is probably by increasing the size of the animal's lenght, more food resources would approach to the infested parasites, which certainly increases the number of parasites too and on the other hand, length increasing would result in increasing host body size and gills surface area of the animal which means that, accessability of free-living forms of parasite to inhabit on bigger crayfish could be possible with more facility. Within the study it was discovered that prevalence value in female sex is higher $(47 \%)$ than male sex $(36.6 \%)$, but mean intensity in female sex is slightly lower than male one. In other word, occurrence of Branchiobdellids infestation in freshwater crayfish is a sex dependent parameter and has a positive correlation between prevalence value and crayfish sex, hence it could vary with crayfish sex, while this issue is in contrary to that found by Mori, et al. (2000) [4]; which remarks "In Ligurian crayfish populations, the rates of infestation of B. italica are independent of crayfish sex, and are greater in larger size crayfish than in smaller size". Recent survey also expressed that, the number of infected crayfish which involved on carapace by Branchiobodella sp. (52 number) were higher than on gills (34 number). Meanwhile; fre- 
quency, prevalence value and mean intensity of these worms on carapace was maximum, compared to gills. According to some researcher's statements, Branchiobdellian were usually detected on gill chambers and cephalothoracic base. And only in bigger or male crayfish occupies other parts of the body [23]. The scarce presence of branchiobdella on bronchial chambers in compare with carapace appears common, since the wide surface of their carapace seems to have a favorable substratum for the worm settlement. Their scarcity could be due to the strong competition for space and food, that these small worms have to withstand, as [22] seen diatoms, rotifers, detritus and chironomid larvae in the gastric contents of $B$. pentodonta, a congener ectocommensal species of $B$. italica. Where infections of $B$. hexodonta or other parasitic species occur on crayfish gills, melanisation of the gill filaments is common place at points where the parasite has grazed on the host. It is not supposed to parasitic Branchiobdellids are responsible for crayfish mortalities. Constant wounding does provide a route of entry for pathogenic micro-organisms, particularly when the numbers of branchiobdellids are higher than normal. Hubault (1935) [24] observed a mortality of $A$. pallipes where very high numbers of $B$. parasitica (Figure 4) were found, but bacteria were also present in the blood, means that although branchiobdellids may have facilitated the entry of the pathogen, they were not being the primary cause of the mortality [11].

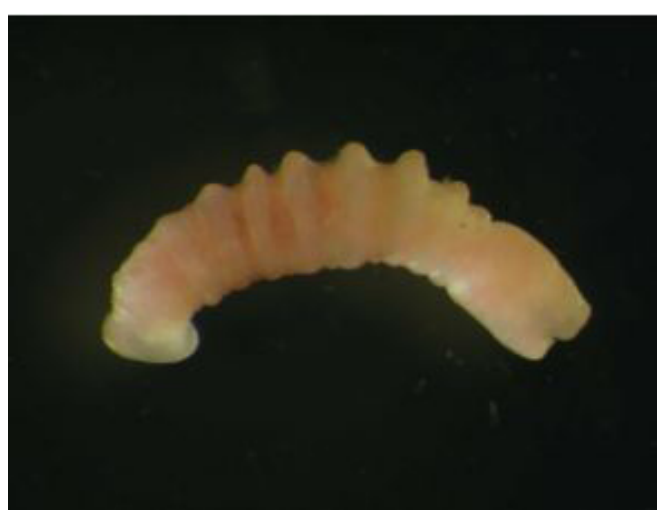

Figure 4: Branchiobdella parasite recovered from freshwater cray fish Rhabdochona sp. Cystidicola sp.

According to a report (Meike, 1999) [15], freshwater crayfish appearance and morphology is necessary for passing reproduce cycle process of Branchiobdella sp. To other mean, crayfish is specific host for the parasite and the worm is arbitrary parasite of crayfish. Authors research has also mentioned that a given species of Branchiobdellid may be found on one part of the crayfish in summer (e.g. Branchiobdella parasitica around the eyes, claws and pleopods of Astacus astacus) and another part in winter (principally the abdomen) [11]. The stage of development of the brachiobdellid may also affect the part of the host body on which it is found [25]. It's worthy of mention, that none of the crayfish internal organs have been infested to parasite, also human infec- tion with this parasite has not yet been reported. Rabdochona sp. and Cystidicola sp. nematodes larvae (Figure 5) which have been present in this research are freshwater fish intestine parasite fauna and were found on bronchial chambers of crayfish "Astacus leptodactylus" and all are external or epicommensals [26].

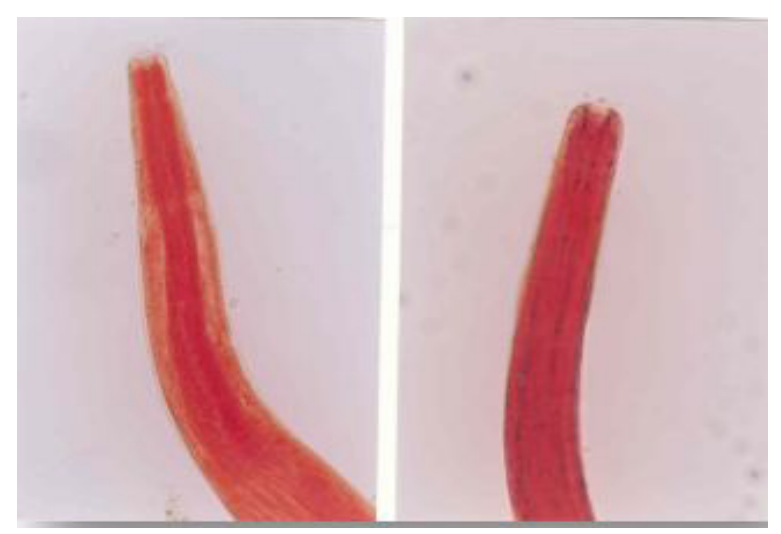

Figure 5: Two Nematodes Larvae Retrieved from Freshwater Crayfish "Astacus Leptodactylus" Gill in Arass Dam Lake, Stained with Acetocarmine, Magnification 200X(Original).

These nematodes may be commensal with crayfish or having free-living style and crayfish would act as an intermediate host for them. It should be noted that Annelida Branchiobdella sp. is an arbitrary parasite for freshwater crayfish "Astacus leptodactylus" and crayfish is counted as specific host of the parasite [27]. There are several researches were performed about fish parasitic infections and diseases in Iranian inland water reservoirs, but there is no report about crayfish diseases, infestations or parasitic infection, and this is the first study of its own right. In this investigation Annelida "Branchiobdella hexodonta" which known as crayfish "Branch worm" was discovered from freshwater crayfish "Astacus leptodactylus" spices for the first time in Iranian inland water resources. by the way, this worm only has parasitism freshwater crayfish and is host specific for the crayfish "Astacus leptodactylus" [28]. Finally, none of the nematode larvae, Rhabdochona sp. and Cystidicola sp. have parasitic role, but have Commensal state or free style living form. They are retrieved from gills, and crayfish act as a vector for them. Cystidicola sp. parasite only was known from freshwater inhabitants, where they were infected intermediate and definitive hosts. Presence of Cystidicola sp. indicates that these crayfish feed on tiny freshwater crustaceans. In current review, the only acquired species from "Astacus leptodactylus" was $B$. hexodonta, it's may be due to the difference in climatic and geographical location of natural habitat of the crayfish [29].

\section{Acknowledgment}

I would like to thank and appreciate Dr Khanipoor, the head and manager of inland waters aquaculture institute in Guilan province for his useful assistance and honest cooperation with this research 


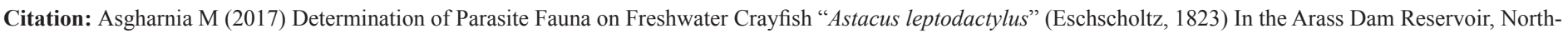
west of Iran. J Fish Aqua Dev: JFAD-128.

project and his valuable suggestions and guidance.

\section{References}

1. Smith AJ, Chisholm JRS (1992) Non-cellular immunity in Crustaceans. Fish and Shellfish Immunology 2 : 1-31.

2. Evans LH, Fotedar, Fan A, Jones B (1999) Investigation of idiopathic muscle necrosis and circulating hemocytes in the freshwater crayfish Cherax tenuimanus exposed to acute and chronic stressors. Freshwater crayfish 12: 356-370.

3. Evans L, Chan V, Fotedar S, Jussila J, Tsvetnenko E (2000) Influence of environmental stressors on immunocompetence in the spiny lobster Panulirus cygnus: implications for lobster aquaculture. In: AQUA 2000. Resposible Aquaculture in the New millennium, (eds R Fop \& $L$ Creswell), P. 206. European Aquaculture Society special publication, Oostende, Belgium.

4. Mori M, Rosso E, Salvidio S (2000) Presence and incidence of Branchiobdella (Annelida, Branchiobdellidae) in the Ligurian ashtrays populations. Ann. Mus. Civ. St. Nat. Giacomo Doria, Genova 93: 211-224.

5. Evans L, Paganini M, Fan A, Fotedar S, Fotedar R, et al. (1999) Acute and chronic stress studies in freshwater crayfish. World Aquaculture 99: 249.

6. Thune R (1994) Diseases of Louisiana crayfish. In: Freshwater Crayfish Aquaculture in North America, Europe and Australia, (ed. J.V. Huuner) Food Products Press, New York 11: 117-156.

7. Goodnigh CJ (1940) The Granchiobdellidae (Oligochaeta) of North American crayfish. Illinois Biological Mongraphs 17: 1-75.

8. Gelder SR (1996) A review of the taxonomic nomenclature and a checklist of the species of the branchiobdellae (Annelida: Clitellata). Proceedings of the Biological Society of Washington 109: 653-663.

9. Holt PC (1976) The branchiobdellid (Annelid: Clitellata) associates of Astacoidean Crawfishes. Freshwater crayfish 2 : 337-346.

10. Holt PC (1973b) A free-living branchiobdellid (Annelida: Clitellata)? Transactions of the American microscopical Society 92: 152-153.

11. Simon JL (1977) Current data on the pathology of crayfish In Europe. Doctoral Thesis, University of Paris (Val_de_Marne) and National Veterinary School Alfort.

12. Smietana P, Wierzbicka J (1999) Species of Branchiobdella Odier, 1823 (Annelida: Clitellata) associated with the crayfish Astacus astacus and Astacus leptodactylus in Poland. Freshwater Crayfish 12: 349-355.

13. Tuusti J, Paaver T, Reier A (1993) Situation of the noble crayfish (Astacua astacus) Stocks in Estonia. Freshwater Crayfish 9: 163-169.

14. Bohl E (1999) Motion of individual noble crayfish Astacus in different biological Situations: in-situ studies using radio telemetry. Freshwater Crayfish 12: 677-687.
15. Meike E (1999) The relationship between Branchiobdella sp. (Annelida, Oligochaeta) and its host, the noble crayfish (Astacus astacus). Archiv für Hydrobiologie 144: 357-359.

16. Pennak RW (1978) Freshwater invertebrates of the United States. Renard press, New York.

17. Gelder SR, Delmastro GB, Ferraguti M (1994) A report on Brachiobdellidans (Annelida: Clitellata) and a taxonomic key to the species in northern Italy, including the first record of Cambaricola mesochoreus on the introduced American red swamp crayfish. Boll Zool 61: 179183.

18. Alderman DJ, Polglase JL (1988) Pathogens, Parasites and commensals. In: D.M. Holdich \& R.S. Lowery (Eds), Freshwater crayfish. biology, management and exploitation. Croom Helm London 167-212.

19. Mazzarelli G (1903) the «Branchiobdellosi» of the shrimp. L' Lombard Aquaculture 5: 1-10.

20. Young W (1966) Ecological studies of the Branchiobdellidae (oligochaeta). Ecology 47: 571-578.

21. Grabda E, Wierzbicka J (1969) The problem of parasitism of the species of the genus Branchiobdella. Pol Arch Hydrobiol 16: 93-104.

22. Vogt G (1999) Disease of European freshwater crayfish, with particular emphasis on interspecific transmission of pathogens. In: Crayfish in Europe as alien species: How to make the best of a bad situation? Crustacean Issues, Balkema AA, Rotterdam Brookfield 11: 87-103.

23. Cenni F, Crudele G, Gherardi F, Mori M (2002) Infestation rate of Branchiobdellids in Austropotamobius pallipes italicus from a stream of central Italy: Preliminary results. Bull Fr Pêche piscic 367: 785-792.

24. Hubault E (1935) An epizootic on potamobius pallipes lereboullet. Ann parasitol hum Comp 2 : 109-112.

25. Jensen O (1947) The parasites and commensals of Minnesota crayfish Orconectes virilis (Hagen). Ph.D thesis, University of Minnesota.

26. Hobbs HH, Jr, Villalobos A (1958) The exoskeleton of a freshwater crab as a microhabitat for several invertebrates. Va J Sci 9: 395-396.

27. Karaman M (1967) Branchiobdellidae Jugoslavije. Zbornik Filozofskog fakulteta u Prištini IV : 39-64.

28. Roberts RJ (1989) Fish pathology. Bailliere Tindall. London, England.

29. Van Damme PA, Maertens D, Arrumm A, Hamerlynck O, Ollevier FJ (1993) The role of Callionymus lyra and C. reticulates in the life cycle of Lernaeocera lusci in Belgian coastal Waters (Southern Bight of the North Sea) J Fish Biol 42: 395-401. 